\title{
Two Ways of Processing Language: Associative Memory and Computational Rules in the Case of Modern Polish ${ }^{1}$
}

Mirosław Koziarski, Adrian P. Krysiak

(Poznań)

\begin{abstract}
This paper discusses associational and computational approaches to language and cognition with a special focus on modern Polish. The authors indicate the sources for both views and try to combine these views in order to answer the underlying question of how language is processed. The analysis of Polish morphology (scil. verb inflection) has shown that such a combination is possible and scientifically valuable but still more specific research on the neuronal correlates of linguistic behaviours is needed.
\end{abstract}

\section{Introduction}

There are two main approaches to language and cognition. One, called associationism, attempts to explain the given phenomena in terms of associative memory structure and considers the brain as ,a homogenous network of interconnected units modified by a learning mechanism that records correlations among frequently co-occurring input patterns" (Pinker 1991). The other, under the collective name of rule-and-representation theories, treats the brain as a computational device in which rules operate on symbolic representations (ibid.).

The authors wish to thank Dr Sz. Grzelak, Dr P. Nowakowski and E. Mowinski for their invaluable help and commitment in preparing and editing this paper. Needless to say all deficiencies and errors are ours. 


\section{Language, memory, and consciousness}

The mutual correlations between language and memory have been corroborated by numerous studies (e.g. Ojemann/Mateer 1979; Greenfield, Savage-Rumbaugh 1993; Glenberg 1997; Aboitiz et al. 2006; Szepietowska/Oroń 2008). It has also been well-established that these interconnections may be used in many subfields of linguistics such as language acquisition (Jusczyk, Hohne 1997) and evolutionary linguistics. In fact, many theorists, aware of the explanatory force of the idea at hand, highlight the role of memory in the process of language evolution (e.g. Aboitiz, García 1997; Aboitiz et al. 2006; Gorzelańczyk, Nowakowski 1999; Krysiak 2010a). Although Fitch (2000) points out two crucial prerequisites for modern human speech abilities, i.e. (i) modification of vocal tract morphology and (ii) development of vocal imitative ability, Aoki and Feldman (1989) model the hypothesis that greater memory capacity may have been a prerequisite for speech. Of course, it should not be forgotten that the influence was reciprocal, which means that the structure of language might have made it possible to minimize memory load, which in turn could have been an adaptive trait. Given the fact that the self is based on the memory (autobiographical memory) (Conway 2005), all three phenomena are strictly connected and therefore ought to be investigated inseparably. Even though Damasio (1998) distinguishes between core consciousness and extended consciousness, with the latter being enhanced by language, for some authors (Gorzelańczyk, Nowakowski 1999) the distinction is only a quantitative one. All in all, language is here regarded in a broader sense, i.e. as a way of communicating between individuals, and is tied to the general mechanisms of memory and consciousness (cf. Gorzelańczyk, Nowakowski 1999).

Despite the fact that some authors consider language acquisition in terms of general learning processes (Christiansen 2005; Christiansen, Chater 2008), we look for neural correlates of phenomena such as learning and memory. From a neurobiological point of view, memory is mainly based on long-term potentiation (LTP) (Longstaff 2006), a process significant to stem plasticity that is used in some 
functional neuroscientific models (Gorzelańczyk et al. 2005). Thus we insist that the pure ability of learning language is genetically encoded and that the realization requires external information.

\section{Lingua ex Machina?}

Some supporters of the rule-and-representation theories suggest that the brain consists of modular computational systems in which language is included (Fodor 1983; overview in Barrett, Kurzban 2006). The associationists, on the other hand, say that ,[t]he mind can be described as a network of interconnected systems and subsystems" (Prinz 2006) and, the neural device involved in language is embedded into a large-scale neurocognitive network comprising widespread connections between the temporal, parietal and frontal (especially prefrontal) cortices" (Aboitiz/García 1997).

There are studies confirming each of these underlying ideas (e.g. Bybee/Slobin 1982; Gupta/Tisdale 2009), which make some authors (Pinker 1991, 1998; Aboitiz et al. 2006) come to the conclusion that both approaches are partly right. Some quantitative studies on English grammar (e.g. Stanners et al. 1979; Prasada, Pinker 1993; Alegre/Gordon 1999) indicate the possibility that associative memory structure and computational rules both play distinctive roles in language processing. Particularly, a computational symbolic processing module was proposed for regular inflection and a lexical associative storage for irregular morphology, which means that regular morphological forms are constructed by adding suffixes and irregular forms are stored as individual items in the lexicon (e.g. Jaeger et al. 1996; Ullman et al. 2005). ${ }^{2}$

„A grammar defines a mapping between sounds and meanings, but the mapping is not done in a single step but through a chain of intermediate data structures, each governed by a subsystem." (Pinker 1991; cf. Krysiak 2010b)

A review of models of lexical access - see Gleason, Bernstein Ratner (2005). 
Since language is inherently biological in origin (Pinker/Bloom 1990; Aboitiz/García 1997; Gorzelańczyk/Nowakowski 1999; Krysiak 2010a,b), it should come as no surprise that much data on the neuropathologies and genetic defects and their impact on the English language processing support the above-mentioned view (Marin et al. 1976; Gopnik 1990; Gopnik/Crago 1991).

The whole issue seems even more complicated from a neurolinguistic point of view. Although fMRI (functional Magnetic Resonance Imaging) (Ullman et al. 1997; Huang et al. 2002; Beretta et al. 2003), ERP (Event-related potential) (Newman et al. 2007) and PET (Positron Emission Tomography) (Jaeger et al. 1996; Indefrey et al. 1997) studies have revealed that different cerebral regions are active during regular and irregular inflection processing and that irregular forms are processed relatively slower, a metaanalysis (Indefrey 2000) has shown that:

[T] he common activations of regular and irregular verbs are in fact more robust than the differences. (...) this finding does not support dual process models. The evidence provided by PET and fMRI data is therefore, at present, inconclusive with respect to the matter of single versus dual process models of inflectional morphology (Indefrey 2000).

What is more, the development of irregular past tense verbs depends on their frequency (Shipley et al. 1991). No such in-depth research has been conducted specifically for the Polish language so far.

\section{The case of modern Polish}

Modern Polish is an interesting case, as it seems to elude the standard bipolar view on the issue of associationism versus computationism. Polish is a Slavic language that originated from a group of dialects of Proto-Slavic more than a thousand years ago. However, in many ways similar to other Slavic languages, Polish has been 
profoundly influenced by major Western and Slavic languages as well, due to Poland's unique history and geopolitical situation. It has therefore undergone many morphonological changes from outside sources, which has added to the overall complexity of the Polish inflection system.

The significance of Polish in the struggle between associationism and computationism lies in the fact that neither structuralistic nor cognitivistic approaches alone seem to fully encompass the inner workings of the Polish inflectional system. Even though Polish seems to have an inner, highly coherent system of inflection that supports the theory of computationism and a structuralistic approach, the sheer number of classification and stem changes a word can undergo seems to reinforce arguments of associationists and a typically cognitivistic approach. Still, both of these approaches are difficult to prove or disprove entirely.

For the sake of simplicity, the Polish inflection system described in this work will be discussed primarily in the context of foreign language learning, as one that is more viable for empirical experiments and comparison. Also, due to the vastness of the Polish inflectional system, this work will focus on verb conjugation in the Present-Future tense and its relation to the infinitive.

The Present-Future tense (pol. czas teraźniejszo-przyszły) is an actual merger of two tenses traditionally seen as separate by the native speakers of Polish: the Present Tense (pol. czas teraźniejszy) and the Future Simple Tense (pol. czas teraźniejszy prosty). However, these tenses share conjugative patterns and the only difference between them is that the Present Tense can only be obtained from imperfective verbs, and the Future Tense - from their perfective counterparts. This tense, seen as one entity, is also the most frequently used one, and comprises the highest amounts of irregularities.

The complexity of the Polish inflective system has been a challenge to Polish linguistics for over a century now. Although several detailed approaches have emerged in the early $20^{\text {th }}$ century, they were either too complex or too inaccurate for practical application other than as a scientific reference, and little progress has been made in achieving a middle ground. To understand how extraordinary a case 
Polish is in terms of associationism and computationism, one needs to see how elusive the language is when it comes to conjugation. Even though Polish utilizes relatively simple suffixation and prefixation as the main means of inflection, vowel mutations and consonant alternations frequently occur. However, these two morphonological processes are profoundly intertwined with the suffix conjugation. Conjugation of the verb ending is a problem on its own, as there is more than one standard model for the Polish inflection.

One of the main standard models for Polish conjugation is Jan Tokarski's division into types (Jagodziński 2010). Tokarski classifies verbs by their ending, obtaining eleven main types (eighteen with subtypes). All of the types are presented in Table 1.

Table 1 - Tokarski's Types

\begin{tabular}{|c|c|c|c|c|c|}
\hline Type & Suffix & Example & Type & Suffix & Example \\
\hline I & ać & czytać & VIla & eć & cierpieć \\
\hline II & eć & rozumieć & VIIb & eć & usłyszeć \\
\hline III & $\sim e c ́$ & posmutnieć & VIIla & ywać & zapisywać \\
\hline IV & ować & atakować & VIIIb & iwać & zaskakiwać \\
\hline Va & $\sim$ nąć & ciągnąć & IX & ać & wiązać \\
\hline $\mathrm{Vb}$ & $\sim$ nąć & wysunąć & $x$ & $\sim c ́$ & bić \\
\hline Vc & nąć & chudnąć & Xla & $\sim c ́$ & lać \\
\hline Vla & ić & chwalić & XIb & ąć & zdjąć, giąć \\
\hline VIb & yć & mierzyć & $\mathrm{XIc}$ & $\sim \dot{c}, \sim \mathrm{C}$ & nieść, tłuc \\
\hline
\end{tabular}

This approach provides detailed conjugative patterns with almost no exceptions, yet it is a very impractical one. Not only the sheer number of types seems unlikely to be consciously utilized by speakers of Polish (both native and non-native), it contains much overlapping in endings, i.e. classes I and IX, classes II, III and VII etc. In other words, the infinitive ending - the base of classification into types - is not enough to predict without any prior knowledge to which type a verb belongs. Even though scientific value of Tokarski's 
approach should not be entirely discarded, there is little use for it in real-time language use.

Another mainstream approach to Polish verbs has been created by Stanislaw Szober (Jagodziński 2010). His look on the problem. however, turns out to be more critical as it recognized the multilayered complexity of Polish conjugation. Szober's input into the verb classification comprises three different angles: division into thirteen classes, six clusters and four conjugations.

Even though Szober's classes bear resemblance to Tokarski's types, Szober based his classes on the relation between different conjugational forms rather than on one (infinitive) form alone. The key forms used in classes division are doublets and triplets that comprise the Present-Future Tense stem (first and second person singular) and the Past Tense stem (third person singular of masculine and masculine-personal gender). The table below lists classes and their stem doublets and triplets:

Table 2 - Szober's Classes

\begin{tabular}{|l|l|l|}
\hline Class & Suffix Duplets/Triplets & Example \\
\hline 1. & $\begin{array}{l}\text {-uj- : -owa-; } \\
\text {-uj- :-ywa-/-iwa- }\end{array}$ & $\begin{array}{l}\text { kupuje : kupował; } \\
\text { pisuje : pisywał; podsłuchuje } \\
\text { podsłuchiwał }\end{array}$ \\
\hline 2. & - ej- :-e/a- & $\begin{array}{l}\text { siwieje : siwiał, siwieli; bieleje : bielał, } \\
\text { bieleli }\end{array}$ \\
\hline 3. & $-n-:$-ną/nę- & $\begin{array}{l}\text { płynie : płynął, płynęli; mknie : mknął, } \\
\text { mknęli }\end{array}$ \\
\hline 4. & $-j-:-0-$ & pije : pił; czuje : czuł; żyje : żył \\
\hline 5. & $-t,-d,-s,-z,-k / c z,-g / z ̇$ & $\begin{array}{l}\text { plecie : plótł; niesie : niósł; piekę, } \\
\text { piecze : piekł }\end{array}$ \\
\hline 6. & $-w:-w-a-,-s:-s-a-$ & rwę, rwie : rwać; ssę, ssie : ssać \\
\hline $7 a$. & $-r / r z:-a r,-r z e$ & trę, trze : tarł, trzeć \\
\hline $7 b$. & $-r / r z:-r-a-$ & biorę, bierze : brał, brać \\
\hline 8. & $-m:-a,-n:-a ̨$ & dmę : dął, tnę : ciął \\
\hline
\end{tabular}


Mirosław Koziarski, Adrian P. Krysiak

\begin{tabular}{|l|l|l|}
\hline 9. & $(-\mathrm{j}):-\mathrm{a}-$ & piszę, pisze : pisał; łapię, łapie : łapał \\
\hline 10. & $\begin{array}{l}-\mathrm{i}-, \\
-\mathrm{y}-\end{array}$ & $\begin{array}{l}\text { robię, robi : robił; bronię, broni : bronił; } \\
\text { suszę, suszy : suszył }\end{array}$ \\
\hline 11. & $\begin{array}{l}\text {-i- : -e/a-, } \\
-\mathrm{y}-: \text {-e/a- }\end{array}$ & $\begin{array}{l}\text { widzę, widzisz : widział, widzieli; } \\
\text { słyszę, słyszy : słyszał, słyszeli }\end{array}$ \\
\hline 12. & $-\mathrm{a}-$ & czytam, czyta : czytał, czytali \\
\hline 13. & $-\mathrm{e} / \mathrm{a}-$ & umiem, umie : umiał, umieli \\
\hline
\end{tabular}

This approach is much more unambiguous than Tokarski's types (though not completely so), and it takes some consonant alternations into consideration. However, to ascribe a verb to a given class, a prior knowledge of at least two forms of the verb is required. Moreover, different classification criteria for each class make this system confusing as well, not to mention the still high number of patterns to be reckoned with.

Szober also proposed dividing verbs by clusters. This division is much simpler than the previous one, as it utilizes only the Past Tense stem for cluster identification and there are only six clusters altogether. However, as previously seen, there are stem overlaps between some clusters, which reduces the usability of this division in identifying the kind of verb one is dealing with. The main reason for these overlaps is that membership of a given verb in a concrete group depends on the character of the final vowel (whether it is a part of the root or not), and verbs whose infinitives end with $-i c \dot{c},-y c$, $-a c^{\prime}$ can cause problems. The clusters are the following:

Table 3 - Szober's Clusters

\begin{tabular}{|l|l|l|}
\hline Cluster & Suffix & Example \\
\hline 1. & -ał, -ali & $\begin{array}{l}\text { pisać: pisał, pisali; czytać: czytał, } \\
\text { czytali; brać: brał, brali }\end{array}$ \\
\hline 2. & - ał, -eli & $\begin{array}{l}\text { widzieć: widział, widzieli; słyszeć: } \\
\text { słyszał, słyszeli }\end{array}$ \\
\hline 3. & $-i \nmid /-y ł,-$-ili/-yli & $\begin{array}{l}\text { robić: robił, robili; bronić: bronił, bronili; } \\
\text { suszyć: suszył, suszyli }\end{array}$ \\
\hline
\end{tabular}


Two Ways of Processing Language: Associative Memory and Computational Rules in

\begin{tabular}{|l|l|l|}
\hline 4. & $-n a ̨ ł,-n e ̨ l i$ & $\begin{array}{l}\text { płynaćc: płynął, płynęli; mknąć: mknął, } \\
\text { mknęli }\end{array}$ \\
\hline 5. & $-\nmid,-l i+$ vowels & $\begin{array}{l}\text { pić: pił, pili; czuć: czuł, czuli; być: był, } \\
\text { byli }\end{array}$ \\
\hline 6. & $-\nmid,-l i+$ consonants & $\begin{array}{l}\text { jeść: jadł, jedli; piec: piekł, piekli; trzeć: } \\
\text { tarł, tarli }\end{array}$ \\
\hline
\end{tabular}

The last of Szober's approaches is much simpler than the previous ones and broadly acclaimed (sporadically with some minor improvements) - mostly because of its simplicity, as it is divided into just four groups. This classification is based on the first and second person singular in the Present-Future Tense. The conjugations look like these:

Table 4 - Szober's Conjugations (key forms in bold)

\begin{tabular}{|l|l|l|l|l|l|l|}
\hline \multicolumn{2}{|c|}{ Conjugation I } & \multicolumn{4}{c|}{ Conjugation II } \\
\hline & Singular & \multicolumn{1}{|c|}{ Plural } & & \multicolumn{2}{c|}{ Singular } & Plural \\
\hline 1. & $-e$ & -emy & 1. & $-e$ & -imy/-ymy \\
\hline 2. & -esz & -ecie & 2. & -isz/-ysz & -icie/-ycie \\
\hline 3. & -e & -ą & 3. & -i/-y & -ą \\
\hline \multicolumn{2}{|c|}{ Conjugation III } & \multicolumn{4}{c|}{ Conjugation IV } \\
\hline & Singular & \multicolumn{1}{|c|}{ Plural } & & \multicolumn{2}{c|}{ Singular } & Plural \\
\hline 1. & -am & -amy & 1. & -em & -emy \\
\hline 2. & -asz & -acie & 2. & -esz & -ecie \\
\hline 3. & -a & -aja & 3. & -e & -eją/-edzą \\
\hline
\end{tabular}

Even though there are no ending overlaps between the first two forms, it is often (but not always) difficult to predict what conjugation a verb belongs to without knowing two key forms - namely the first and the second person singular. Moreover, first and second conjugations are very prone to morphonological changes. These changes comprise vowel mutation $\mathbf{0}: \mathbf{e}$, prolongation of the vowel $i: i j$ and a 
set of consonant alternations, as follows: $m: m^{\prime}, n: n^{\prime}, w: w^{\prime}, d: d z$,

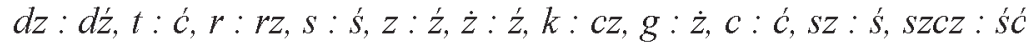
and $\dot{z} d \dot{z}$ : źdź (Bartnicka, Satkiewicz 2007; Bak 2007). Although most frequent stem changes are limited to the first and second group, the remaining groups are not entirely regular, either. Hence, apart to the „regular" knowledge of the Polish conjugation system, one is required to possess additional knowledge about the possible stem changes and irregularities in order to inflect properly.

It would be reasonable to juxtapose these approaches and look at where they overlap or supplement each other, and where they are contradictory. However, since these approaches utilize different criteria, they seem to be incompatible. For example, the verb spać 'to sleep' is irregular in the classic approach (division into classes), yet it is perfectly regular as a member of Conjugation II; similarly, while kupowac 'to buy' is a sub variation of Conjugation I, it is a regular Class 1 verb. There are more discrepancies of such kind that have prevented linguists from creating a neat unification theory for the Polish verb.

Zygmut Saloni has attempted to create a classification of verbs using all possible denominators in his book entitled Czasownik polski (Saloni 2007). Even though his patterns encompass all typical verbs present in Polish, there are 103 of them, and many patterns have only one member (plus its prefixed variations). As good as it may be as an occasional reference, the sheer number of patterns might be overwhelming. But it does not mean that a complex solution cannot be achieved.

As the strictly computational approach is clearly insufficient to tackle the problem of Polish conjugation, and a strictly associative approach would contradict all inflectional methods, we tried to locate a middle grounds for Polish inflection. In order to do this a new set of criteria were selected. The first stage was to separate all stems that verb conjugates can have. Six main stems in the Polish verb have been separated. The verb wziqci 'to take' illustrates this idea very well, since all six stems differ in this case:

1. wziqc - the infinitive form 
2. wezme - first person singular of the Present-Future Tense (always equals the third person plural stem)

3. weźmiesz - second person plural of the Present-Future Tense (always equals the three remaining Present-Future Tense personal forms)

4. weź - second person singular of the Imperative

5. wziat - third person singular of the Past Tense in the masculinepersonal gender

6. wzieli - third person singular of the Past Tense in the feminineobjective gender

Note that the remaining three genders in the Past Tense agree with either stem four or stem five. Additionally, some or even all of these key stems might overlap - a good example for the latter is the verb mydlic' 'to soap', which has one stem shared by all it conjugates (1. mydlić; 2. mydlę;3. mydlisz; 4. mydl; 5. mydlit; 6. mydlita). However, since this work is focused on the infinitive and the PresentFuture Tense, only the three first forms are important.

As previously mentioned, stem changes are strictly connected to the ending inflection. The following table presents Szober's Conjugation with stem change marked with the acute accent (') to mark vowel mutation/prolongation, palatalization or vowel alternation:

Table 5 - Szober's Conjugations and stem change markers (key forms in bold)

\begin{tabular}{|c|c|c|c|c|c|}
\hline \multicolumn{3}{|c|}{ Conjugation I } & \multicolumn{3}{|c|}{ Conjugation II } \\
\hline & Singular & Plural & & Singular & Plural \\
\hline 1. & $-e ̨$ & -'emy & 1. & -'ę & -'imy/-ymy \\
\hline 2. & -'esz & -'ecie & 2. & -'isz/-ysz & -'icie/-ycie \\
\hline 3. & -'e & -ą & 3. & -'i/-ysz & -'ą \\
\hline \multicolumn{3}{|c|}{ Conjugation III } & \multicolumn{3}{|c|}{ Conjugation IV } \\
\hline & Singular & Plural & & Singular & Plural \\
\hline 1. & -am & -amy & 1. & -'em & -'emy \\
\hline 2. & -asz & -acie & 2. & -'esz & -'ecie \\
\hline 3. & $-a$ & -ają & 3. & -'e & -'eją/-edzą \\
\hline
\end{tabular}


Now that all endings are listed and their influences over the verb stem are marked, the stem changes alone remain the irregular factor, seemingly sending the anlysis back to square one. However, taking the endings and the morphonological changes (henceforth - MPC) as constants, the only variable that remained was the relation between the three stems that were singled out for comparison (the infinitive stem and the first and person singular of the Present-Future Tense stems). Based on the compliance of the stems of verb conjugates, three main Stem Classes of verbs emerged:

1. Regular verbs: all three stems are identical

2. Semi-regular verbs:

a) MPC I: first and second person singular stems are identical, the infinitive stem is different

b) MPC II: the infinitive and the first person singular stems are identical, second person singular stem is different

c) MPC III: the infinitive and the second person singular stems are identical, first person singular stem is different

3. Irregular verbs: all three stems are different

The classification at hand revealed itself as having small extremes and putting a significant amount of verbs ,,in the middle", i.e. classifying them as semi-regular. The results were then compared with two of Szober's approaches. Conjugations and Classes. These have proven to be only partially compatible with the present approach. For each of these Stem Classes, verbs were subdivided by their Conjugation and their Class was marked (asterisk [*] stands for irregular verbs in the Classes division):

Stem Class 1: Regular verbs (all three stems are identical) encompasses majority of verbs from Conjugation II and almost all verbs from Conjugation III:

- Conjugation II (soft consonat ending): $s p a c^{*}, m^{\prime} w i c ́$ VIa, robić ${ }^{\mathrm{VIa}}$, mydlić ${ }^{\mathrm{VIa}}$, czytać $^{\mathrm{I}}$, molleć $c^{\mathrm{III}}$

- Conjugation II (hardened consonants - obligatory: $c z, s z c z$;

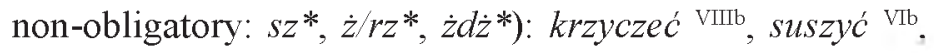
shużyć ${ }^{\mathrm{VIb}}$, miażdzyć $\mathrm{VIb}$ 
- Conjugation III (without the verb dać 'to give' and its prefixed variants):

- Conjugation III: mieć ${ }^{*}$, czytać $^{\mathrm{I}}$, plywać $^{\mathrm{I}}$, kochać $^{\mathrm{I}}$, uciekać $^{\mathrm{I}}$, narzekać ${ }^{1}$

Stem Class 2: Semi-regular verbs (MPC I and MPC II) encompass only Conjugation I and Conjugation II verbs.

a) MPC I (first and second person singular stems are identical, the infinitive stem is different) encompass only a small part of verbs from Conjugation I:

- Conjugation I (soft and hardened consonants): pić ${ }^{\mathrm{Xa}}$, bić ${ }^{\mathrm{Xa}}$, wyć ${ }^{\mathrm{Xa}}$, myć ${ }^{\mathrm{Xa}}$, plakać $^{\mathrm{IX}}$, skakac $^{\mathrm{IX}}$, chcieć $^{*}$, mielić ${ }^{\mathrm{XI}}$, kupować $^{2}$ IV , atakować ${ }^{\mathrm{IV}}$

b) MPC II (the infinitive and the first person singular stems are identical, second person singular stem is different):

- Conjugation I: ciagnać va zamknqci va , plynać vb, chudnać vc

c) MPC III (the infinitive and the second person singular stems are identical, first person singular stem is different) comprise mainly Conjugation II verbs and one member of Conjugation I:

- Conjugation II (majority of hardened consonants alternating with soft consonants):

$\mathrm{c} \rightarrow$ ć : placić $\mathrm{VTa}-$ place $\rightarrow$ placisz $\mathrm{dz} \rightarrow \mathrm{dź}:$ chodzić $\mathrm{VIa}-$ chodzę $\rightarrow$ chodzisz $\mathrm{sz} \rightarrow \mathrm{s}:$ nosić $\mathrm{Va}-$ noszę $\rightarrow$ nosisz; gasić $\mathrm{Va}-$ gaszę $\rightarrow$ gasisz

$\dot{\mathrm{z}} \rightarrow \mathrm{z}:$ wozić $\mathrm{VIa}-$ wożę $\rightarrow$ wozisz

$\dot{z} d \dot{z} \rightarrow$ źdź : jeździć ${ }^{\mathrm{VIa}}-$ jeżḋ̇e $\rightarrow$ jeździsz

Stem Class 3: Irregular verbs (all three stems are different) are much less discriminating as they comprise verbs from all three Conjugations:

- Conjugation I (hard consonants and Polish mutation): znaleźć $c^{\mathrm{XI}}, i s c^{*}$, siqús ${ }^{*}$, nieść ${ }^{\mathrm{XI}}$, wieść $c^{\mathrm{XI}}$, wieźć ${ }^{\mathrm{XI}}, b r a c^{\mathrm{IX}}$, móc $^{\mathrm{XI}}$, piec ${ }^{\mathrm{XI}}$, wlec $\mathrm{XI}$, biec $\mathrm{XI}$, wziacic ${ }^{\mathrm{Xc}}$, giac $^{\mathrm{Xc}}$, ciqcí $^{\mathrm{Xc}}$

- Conjugation II: stac ${ }^{*}$ - stoję $\rightarrow$ stoisz

- Conjugation III: dać ${ }^{\mathrm{I}}-$ dam $\rightarrow$ dasz (irregular third person plural ending: $d a d z q$ ) 
- Conjugation IV (all verbs): wiedzieć ${ }^{*}$,jeśc ${ }^{*}$, umieć ${ }^{\text {II }}$, rozumieć II ${ }^{*}$

Even though only a representative group of verbs has been presented here, they have all been carefully selected to include the broadest possible spectrum of inflectional and morphonological processes.

\section{Summary}

The results of the present analysis suggest that associationism and computationism are not competing theories, but rather they form a bipolar theory that allows for a middle ground. The classification proposed here not only indicates that with the proper criteria an entire continuum of semi-regularity based on two different morphemes (stem and suffix of the Polish verb). Furthermore, such an approach to the classification of Polish verbs indicates that the regularityirregularity relation is not strictly vertical, but also horizontal namely, there is no self-evident hierarchy between MPC I, MPC II and MPC III subclasses in the semi-regular class of verbs.

Further research should focus on the neurobiological basis of regular and irregular processing in Polish and should be carried out on healthy individuals as well as patients with language disorders (e.g. people suffering from Parkinson's disease, Alzheimer's disease, various forms of aphasia and basal ganglia dysfunctions among others). For the time being it remains sound beyond a reasonable doubt that language is processed in partly regular and partly irregular was and, what is particularly significant, that the opposition of these characteristics is rather quantitative.

\section{Bibliography}

Aboitiz, Francisco/García, Ricardo R./Bosman, Conrado/ Brunetti, Enzo (2006): „Cortical memory mechanisms and language origins”. Brain and Language 98, 40-56. 
Aboitiz, Francisco/García, Ricardo V. (1997): „The evolutionary origin of the language areas in the human brain. A neuroanatomical perspective". Brain Research Reviews 25(3), 381-396.

Alegre, Maria/Gordon, Peter (1999): „Rule-based versus associative processes in derivational morphology". Brain and Language 68, 347-354.

Aoki, Kenichi/Feldman, Marcus W. (1989): „Pleiotropy and preadaptation in the evolution of human language capacity". Theoretical Population Biology 35(2), 181-194.

Barrett, H. Clark/Kurzban, Robert (2006): „Modularity in Cognition: Framing the Debate". Psychological Review 113(3), 628-647.

Bartnicka, Barbara/Satkiewicz, Halina (2007): Gramatyka jezzyka polskiego [Grammar of the Polish language]. Warszawa: Wiedza Powszechna.

Bakk, Piotr (2007): Gramatyka jezzyka polskiego [Grammar of the Polish language]. Warszawa: Wiedza Powszechna.

Beretta, Alan/Campbell, Carrie/Carr, Thomas H./Huang, Jie/ Schmitt, Lothar M./Christianson, Kiel/Cao, Yue (2003): „An ER-fMRI investigation of morphological inflection in German reveals that the brain makes a distinction between regular and irregular forms". Brain and Language 85, 67-92.

Bybee, Joan L./Slobin, Dan I. (1982): „Rules and schemas in the development and use of English past tense". Language 58, 265-289.

Christiansen, Morten H. (2005): „On the Relation between Language and (Mimetic) Culture". http://cnl.psych.cornell.edu/papers/lang-culture. pdf $(23$ X 2010)

Christiansen, Morten H./Chater, Nick (2008): ,Language as Shaped by the Brain". Behavioral and Brain Sciences 31, 489-509.

Conway, Martin A. (2005): „Memory and the self”. Journal of Memory and Language 53(4), 594-628.

Damasio, António R. (1998): „Investigating the biology of consciousness”. Philosophical Transactions of the Royal Society B: Biological Sciences 353(1377), 1879-1882.

Fitch, W. Tecumseh (2000): „The evolution of speech: a comparative review". Trends in Cognitive Sciences 4(7), 258-267.

Fodor, Jerry (1983): Modularity of Mind: An Essay on Faculty Psychology. Cambridge, Mass : MIT Press.

Gleason, Jean B./Bernstein Ratner, Nan (2005): Psycholingwistyka [Psycholinguistics]. Gdańsk: Gdańskie Wydawnictwo Psychologiczne.

Glenberg, Arthur M. (1997): „What memory is for”. Behavioral and Brain Sciences 20 (1), 1-55. 
Gopnik, Myrna (1990): „Feature blindness: A case study”. Language Acquisition 1, 139-64.

Gopnik, Myrna/Crago, Martha B. (1991): „Familial aggregation of a developmental disorder". Cognition 39, 1-50.

Gorzelańczyk, Edward J./Huflejt, Michał/Kniat, Jan/Laskowska, Ewa/ Murakowski, Janusz/Woźniak, Piotr (2005): „Funkcjonalny model symulacyjny zespolu synaps zapamiętujących komórki piramidowej hipokampa" [„The functional model of memorizing pyramidal cell synapses complex in hippocampus"]. Bio-Algorithms andMed-Systems $1-2,217-230$.

Gorzelańczyk, Edward J./Nowakowski, Paweł (1999): „Pamięć, świadomość i biologiczne podloże pochodzenia języka” [„Memory, consciousness and the biological basis of language origin"]. Investigationes Linguisticae 7, 161-172.

Greenfield, Patricia M./Savage-Rumbaugh, E. Sue (1993): „Comparing communicative competence in child and chimp: the pragmatics of repetition". Journal of Child Language 20(1), 1-26.

Gupta, Prahlad/Tisdale, Jamie (2009): „Does phonological short-term memory causally determine vocabulary learning? Toward a computational resolution of the debate". Journal of Memory and Language 61(4), 481-502.

Huang, Jie/Beretta, Alan/Campbell, Carrie/Carr, Thomas H./Christianson. Kiel/Schmitt, Lothar M./Cao, Yue (2002): ,Comparing cortical activation of regular and irregular inflection in German". Proceedings of the International Society for Magnetic Resonance in Medicine. Honolulu. HW. http://cds.ismrm.org/ismrm-2002/PDF5/1486.PDF (23 X 2010)

Indefrey, Peter (2000): „Neural correlates of regular and irregular inflection". 9th International Morphology Meeting, Vienna, 25-27.2.2000. http://www.univie.ac.at/linguistics/tagungen/morphologie/abstracts/ indefrey.pdf ( 23 X 2010)

Indefrey, Peter/Brown, Colin M./Hagoort, Peter/Herzog, Hans/Sach, M./ Seitz, Rüdiger J. (1997): „A PET study of cerebral activation patterns induced by verb inflection". NeuroImage 5 (Suppl), 548.

Jaeger, Jeri J./Lockwood, Alan H./Kemmerer, David L./van Valin, Robert D. Jr./Murphy, Brian W., Khalak, Hanif G. (1996): „A positron emission tomography study of regular and irregular verb morphology in English". Language 72(3), 451-497.

Jagodziński, Grzegorz (2010): A Polish Grammar.

http://grzegorj.w.interia.pl/gram/en/gram00.html (23 X 2010) 
Jusczyk, Peter W./Hohne, Elizabeth A. (1997): „Infants’ Memory for Spoken Words". Science 277, 1984-1986.

Krysiak, Adrian P. (2010a): „Perspektywa bio- i neurolingwistyczna jako nowa determinanta w badaniach nad językiem” [.,Bio- and neurolinguistic approach as a new determinant in linguistic research"]. [in:] Mikolajczyk, Beata/ Taborek, Janusz/ Zabrocki, Władysław (red.): Język w poznaniu 1. Poznań: Wydawnictwo Rys, 97-118.

Krysiak, Adrian P. (2010b): „(Poli)geny na język. Prolegomena do lingwistyki genetycznej” [.,(Poly)genes for language. Prolegomena to genetic linguistics"]. Investigationes Linguisticae XX, 33-39.

Longstaff, Alan (2006): Neurobiologia [Instant Notes Neuroscience] Warszawa: Wydawnictwo Naukowe PWN.

Marin, Oscar S.M./Saffran, Eleanor M./Schwartz, Myrna F. (1976): „Dissociations of Language in Aphasia: Implications for Normal Function". Annals of the New York Academy of Sciences 280, 868-884.

Mizerski, Witold/Dulna-Rak, Ewa/Rucińska, Anna/Kipert, Wojciech/ Kepas, Anna/Bednarczyk, Beata (2000): Jezzyk polski - encyclopedia $w$ tabelach [The Polish language - encyclopedy in tables]. Warszawa: Wydawnictwo Adamantan.

Newman, Aaron J./Ullman, Michael T./ Pancheva, Roumyana/ Waligurad, Diane L./ Neville, Helen J. (2007): An ERP study of regular and irregular English past tense inflection. NeuroImage 34, 435-445.

Ojemann, George/Mateer, Catherine (1979): „Human language cortex: localization of memory, syntax, and sequential motor-phoneme identification systems". Science 28 (205), 1401-1403.

Pinker, Steven (1991): „Rules of Language”. Science 253, 530-535.

Pinker, Steven (1998): ,Words and rules”. Lingua 106, 219-242.

Pinker, Steven/Bloom Paul (1990): „Natural language and natural selection". Behavioral and Brain Sciences 13(4), 707-784.

Prasada, Sandeep/Pinker, Steven (1993): „Generalization of regular and irregular morphological patterns". Language and Cognitive Processes $8,1-56$.

Prinz, Jesse J. (2006): „Is the mind really modular?” [in:] Stainton, Robert J. (ed.) Contemporary Debates in Cognitive Science. Oxford: Blackwell, 22-36.

Rudomina, Justyna/Mamela, Maria (2008): Gramatyka języka polskiego [Grammar of the Polish language]. Toruń: Literat.

Saloni, Zygmunt (2007): Czasownik polski [The Polish verb]. Warszawa: Wiedza Powszechna. 
Saloni, Zygmunt/Gruszczyński, Wlodzimierz/Woliński, Marcin/Wolosz, Robert (2007): Stownik gramatyczny języka polskiego [Grammatical dictionary of the Polish language]. Warszawa: Wiedza Powszechna.

Shipley, Kenneth G./Maddox, Mary A./Driver, Joyce E. (1991): „Children’s Development of Irregular Past Tense Verb Forms". Language, Speech, and Hearing Services in Schools 22, 115-122.

Stanners, Robert F./Neisser, James J./Hernon, William P./Hall, Roger (1979): „Memory representation for morphologically related words". Journal of Verbal Learning and Verbal Behavior 18, 399-412.

Szepietowska, Ewa M./Oroń, Anna (2008): ,Poczucie znajomości i zjawisko mam na końcu języka u chorych na schizofrenię" [,Feeling-of-knowing and tip-of-the-tongue phenomena in patients with schizophrenia"]. Neuropsychiatria i Neuropsychologia 3(2), 60-70.

Szober, Stanisław/Doroszewski, Witold (1968): Gramatyka języka polskiego [Grammar of the Polish language]. Warszawa: Państwowe Wydawnictwo Naukowe.

Ullman, Michael T./Bergida, Ruth/O'Craven, Kathleen M. (1997): „Distinct fMRI activation patterns for regular and irregular past tense”. NeuroImage 5 (Suppl), 549.

Ullman, Michael T./Pancheva, Roumyana/Love, Tracy/Yee, Eiling/Swinney, David/Hickok, Gregory (2005): „Neural correlates of lexicon and grammar: evidence from the production, reading, and judgment of inflection in aphasia". Brain and Language 93(2), 185-238. 